\title{
COMPARISON OF TWO TOTAL RNA EXTRACTION PROTOCOLS FROM CHO-K1 CELLS FOR RT-PCR: CUT- OFF COST FOR RESEARCHERS
}

\author{
VAsila P. Mohamed, Yumi Z.H-Y. Hashim, A. AMID AND M. MeL \\ Bioprocess and Molecular Engineering Research Unit (BPMERU), \\ Department of Biotechnology Engineering, Faculty of Engineering, \\ International Islamic University Malaysia, \\ PO Box 10, 50728, Kuala Lumpur, Malaysia.
}

yumi@iium.edu.my

\begin{abstract}
Various methods have been described to extract RNA from adherent mammalian cells. RNA isolation in conjunction with reverse transcription polymerase chain reaction (RT-PCR) is a valuable tool used to study the gene expression profiling. This approach is now being used in mammalian cell bioprocessing for helping to understand and improve the system. The objective of this study was to compare and determine the most suitable RNA extraction method for CHO-K1 cells in a setting where a relatively large amount of samples were involved. Total RNA was extracted using Total RNA purification kit (without DNase treatment; Norgen, Canada) and RNeasy mini kit (with DNase treatment; Qiagen, USA) respectively. The extracted RNA was then reverse transcribed, and the cDNA was subjected to PCR-amplifying 18S. Yield from RNeasy kit was significantly higher $(0.316 \pm 0.033 \mu \mathrm{g} / \mu \mathrm{l} ; \mathrm{p}=0.004)$ than Total RNA purification kit $(0.177 \pm 0.0243 \mu \mathrm{g} / \mu \mathrm{l})$. However, the RNA purity of both methods was close to 2.0 and there was no significant difference between the methods. The total RNA purification kit is less expensive than RNeasy kit. Since there is no DNase treatment step in the former, extraction time for RNA is shorter. When the extracted RNA was subjected to RT-PCR, both methods were able to show detection of $18 \mathrm{~S}$ at 219 bp. Therefore, this study demonstrates that both protocols are suitable for RNA extraction for CHO-K1 cells. RNeasy mini kit (Qiagen) is recommended if higher yields is the primary issue and the Total RNA Purification kit (Norgen) is recommended if time and cost are concerned.
\end{abstract}

ABSTRAK: Pelbagai kaedah telah digunakan untuk mengekstrak RNA daripada sel mamalia lekat. Pemencilan RNA dengan menggunakan reaksi rantai polimerase transkripsi berbalik (RT-PCR) merupakan kaedah penting yang digunakan dalam mengkaji pernyataan gen berprofil. Pendekatan ini kini digunakan dalam pemprosesan bio sel mamalia untuk memahami dan menambah baik sistem. Tujuan kajian dijalankan adalah untuk menentukan dan membandingkan kaedah ekstraksi RNA yang paling sesuai bagi sel CHO-K1 di persekitaran di mana kadar sampel yang agak besar terlibat. Jumlah RNA diekstrak menggunakan kit penulenan Jumlah RNA (tanpa rawatan DNase; Norgen, Canada) dan kit mini RNeasy (dengan rawatan DNase; Qiagen, USA). RNA yang diekstrak kemudiannya diterbalikkan transkripsi, dan cDNA menjalani penguat PCR 18S. Hasil daripada kit RNeasy adalah lebih tinggi $(0.316 \pm 0.033 \mu \mathrm{g} / \mu \mathrm{l} ; \mathrm{p}=0.004)$ berbanding dengan kit penulenan Jumlah RNA $(0.177 \pm 0.0243 \mu \mathrm{g} / \mu \mathrm{l})$. Walaupun begitu, kaedah penulenan RNA untuk kedua-duanya hampir 2.0 dan tidak terdapat perbezaan yang ketara antara keduanya. Kit penulenan Jumlah RNA adalah lebih murah berbanding dengan kit RNeasy. Memandangkan tidak ada langkah rawatan DNase dengan penggunaan kit Jumlah RNA, tempoh ekstrak RNA nya lebih pendek. Apabila RNA yang telah diekstrak menjalani RT-PCR, kedua-dua kaedah berjaya mengesan $18 \mathrm{~S}$ pada 219 bp. Kesimpulannya, kajian ini menunjukkan kedua-dua kaedah sesuai untuk mengekstrak RNA bagi sel CHO-K1. Kit mini RNeasy (Qiagen) lebih sesuai jika hasil 
yang tinggi diinginkan dan kit penulenan Jumlah RNA (Norgen) pula ideal, jika kos dan masa berkepentingan.

KEYWORDS: CHO-K1; RNA extraction; reverse transcription polymerase chain reaction $(R T-P C R)$

\section{INTRODUCTION}

Chinese hamster ovary ( $\mathrm{CHO}$ ) cells have been widely used in the large scale production of protein. In the biotechnology industry, $\mathrm{CHO}$ is among the most common cell line used in biomedical research and the pharmaceutical industry for production of recombinant proteins [1].

The origin of RNA (e.g. from human, animal or plant), sampling procedures (biopsy material, single cell sampling, laser micro-dissection, tissue) as well as the method of RNA isolation (total RNA or polyadenylated RNA methods) often differs from one laboratory to another [2]. Various methods have been described to extract RNA from adherent mammalian cells, some of which are provided in protocols accompanying various commercially available kits and reagents. These protocols are based on specific principles. Some involve extra steps such as DNase treatment [3] which normally increase the cost. Nevertheless, it is always important to ensure that the RNA extracted is of good quality with sufficient amount in order to successfully perform other downstream techniques in gene expression profiling.

Specifically, DNA-microarray and quantitative reverse transcriptase - polymerase chain reaction (qRT-PCR) are two powerful techniques widely used in functional genomics for the analysis of gene expression profiles [4]. Reverse transcriptase- PCR (RTPCR) allows the amplification and the quantification of previously undetectable amounts of mRNA [5]. Therefore, the objective of this study was to compare two methods to extract total RNA from CHO-K1 cells to be used for RT-PCR. This study is part of our work to optimize media for optimal cell proliferation with emphasis on change at specific gene expression level. This study involves relatively large amount of samples which require RNA extraction protocols. As such, an efficient, time and cost-effective method is of paramount importance to ensure successful and meaningful interpretation of gene expression profiles.

\section{MATERIALS AND METHODS}

\subsection{Supplies}

RNeasy Mini Kit and nuclease-free water were obtained from Qiagen (USA). Total RNA purification kit was obtained from Norgen (Canada). All plastics and nuclease-free plastics tubes were obtained from Orange Scientific (Belgium). Agarose powder was obtained from Promega (USA). The DNA ladder was purchased from Fermentas (Canada).

\subsection{CHO-K1 Cell Line}

CHO-K1 cells (ATCC CCL $-61^{\mathrm{TM}}$ ) were obtained from American Type Culture Collection (ATCC). The cell line was maintained in a RPMI 1640 medium (Mediatech, USA) supplemented with $10 \%(\mathrm{v} / \mathrm{v})$ fetal bovine serum (FBS) at $5 \% \mathrm{CO}_{2} / 37^{\circ} \mathrm{C}$. T-75 flasks were used for cell cultivation. All cultures were initiated at a viable cell concentration $2.0 \times 10^{5}$ cells $/ \mathrm{ml}$. At $70-80 \%$ confluence level, cells were counted and pelleted by centrifugation ( 3 minutes at $1200 \mathrm{rpm}$ ). The cells were resuspended in $0.5 \mathrm{ml}$ 
phosphate buffer saline (PBS) and centrifuged at $2000 \mathrm{rpm}$ for 5 minutes. After the second wash, the supernatant was discarded and cell pellet was stored in $-80^{\circ} \mathrm{C}$ until required.

\subsection{RNA Extraction}

Two different methods to extract total RNA were applied. The following commercially available kits were used: Total RNA purification kit (Norgen, Canada) and RNeasy Mini kit (Qiagen, USA). Total RNA was extracted according to manufacturer's instructions $[6,7]$. The RNA samples were stored at $-80^{\circ} \mathrm{C}$ until further analysis. For the RNA study, three technical replicates were used.

\subsection{RNA Quantity, Purity and Quality Measurements}

The total RNA quantification and purity were determined using a NanoPhotometer ${ }^{\mathrm{TM}}$ Pearl (Implen, Canada). The RNA yield was evaluated by measuring the extinction at 260 $\mathrm{nm}$. Additionally, the $\mathrm{OD}_{260 / 230}$ and the $\mathrm{OD}_{260 / 280}$ ratio showing RNA purity were examined. The issue of RNA quality was assessed by calculating the $\mathrm{A}_{260 / 280}$ ratio to rule out DNA and protein contamination. Obtained values were submitted to student's t-test analysis. For total RNA quality determination, traditional method by gel electrophoresis was used. The integrity of total RNA was assessed on the basis of visualization of $28 \mathrm{~S}$ and $18 \mathrm{~S}$ ribosomal RNA subunits under gel documentation system.

\subsection{RT-PCR of RNA from CHO-K1 Cells}

The reverse transcription (RT) reaction was carried out in a final volume of $20 \mu \mathrm{l}$ RNA samples using SuperScript III Reverse Transcriptase Kit (Invitrogen, USA), according to the manufacturer's instructions.

\subsection{Polymerase Chain Reaction (PCR)}

Primers for amplification of regions of the $18 \mathrm{~S}$ gene sequences were designed and chosen using NCBI, Primer Bank [8] and Primer 3 [9] databases. Sequences of primers used in this study appear in Table 1 . Primers were synthesized by First Base $\left(1^{\text {st }}\right.$ Base, Malaysia). Each amplification reaction comprised of 1x reaction buffer; $0.2 \mathrm{mM}$ dNTPs mix; $2.5 \mathrm{U}$ Taq DNA Polymerase; $2.0 \mathrm{mM} \mathrm{MgCl}_{2}$ (Invitrogen, USA) and $0.3 \mathrm{mM}$ of each primer ( $1^{\text {st }}$ Base, Malaysia). cDNA template of samples and RNase free water were used as negative controls for the amplifications. Amplification profile is depicted as Table 2. Analysis of amplified cDNA fragments were electrophoresed on $2.0 \%$ agarose gels in $1 \mathrm{x}$ TAE buffer, and bands were visualized by ethidium bromide staining and UV transillumination.

\subsection{Statistical Analysis}

Mean RNA yield $(\mu \mathrm{g} / \mu \mathrm{l})$ and purity $\left(\mathrm{A}_{260 / 280}\right.$ ratios $)$ between different RNA extraction methods were compared using SPSS software (t-test). The level of significance was set at $P<0.05$.

Table 1: Primers for $18 \mathrm{~S}$ gene.

\begin{tabular}{cccc}
\hline Gene & \multicolumn{1}{c}{ Sequence } & $\begin{array}{c}\text { Accession } \\
\text { number }\end{array}$ \\
\hline \multirow{2}{*}{$18 \mathrm{~S}$} & $\mathrm{~F}$ & 5'-AGGTCGGTGTGAACGGATTTG-3' $^{\prime}$ & NM_008084 \\
\cline { 2 - 3 } & $\mathrm{R}$ & 5'-TGTAGACCATGTAGTGGTCA-3' $^{\prime}$ & \\
\hline $\begin{array}{l}\text { Note: F=Forward and R= Reverse } \\
\text { The accession number is given for only one representative matching sequence on the NCBI } \\
\text { database (http://www.ncbi.nlm.nih.gov/). }\end{array}$ &
\end{tabular}


Table 2: Amplification profile for $18 \mathrm{~S}$ gene.

\begin{tabular}{lccc}
\hline Steps & Temperature (oC) & Duration & Cycle \\
\hline Pre-denaturation & 94 & $2 \mathrm{~min}$ & 1 \\
Denaturation & 94 & $30 \mathrm{~s}$ & \\
Annealing & 61.0 & $30 \mathrm{~s}$ & 35 \\
Extension & 72.0 & $1 \mathrm{~min}$ & \\
Final Extension & 72.0 & $10 \mathrm{~min}$ & 1 \\
\hline
\end{tabular}

\section{RESULTS AND DISCUSSION}

\subsection{CHO-K1 RNA Yield}

RNA yields from $\mathrm{CHO}-\mathrm{K} 1$ cells obtained through both protocols are summarized in Table 3. The yield was found to be approximately 1.8 times higher for all RNeasy (Qiagen, USA) samples when compared to Total RNA Purification (Norgen, Canada) method. RNA extracted with RNeasy produced the highest amount of RNA (total of 0.316 $\mu \mathrm{g} / \mu \mathrm{l})$. The overall yields seemed to be comparable to those reported for RNeasy and Total RNA purification kit manufacturers.

Table 3: Summary of results from RNA extractions.

\begin{tabular}{|c|c|c|}
\hline Method & $\begin{array}{c}\text { Total RNA Purification } \\
\text { (Norgen) }\end{array}$ & $\begin{array}{l}\text { RNeasy } \\
\text { (Qiagen) }\end{array}$ \\
\hline Sample & CHO-K1 frozen (cell pellet) & CHO-K1 frozen (cell pellet) \\
\hline $\begin{array}{l}\text { RNA yield, } \mu \mathrm{g} / \mu \mathrm{l} \\
\text { (Average } \pm S D ; n=3 \text { ) }\end{array}$ & $0.177 \pm 0.024$ & $* 0.316 \pm 0.033$ \\
\hline Reported RNA Yield & $\begin{array}{l}\text { Up to } 101.5 \mu \mathrm{g} \\
\text { total RNA per sample }\end{array}$ & $\begin{array}{l}\text { Up to } 100 \mu \mathrm{g} \\
\text { total RNA per sample }\end{array}$ \\
\hline $\begin{array}{l}A_{260} / A_{280} \text { Ratio } \\
(\text { Average } \pm S D ; n=3)\end{array}$ & $2.007 \pm 0.035$ & $2.056 \pm 0.027$ \\
\hline DNase Treatment & No & Yes \\
\hline $\begin{array}{l}\text { Estimated Extraction Time of } \\
\text { RNA (hr) }\end{array}$ & 0.2 & 0.4 \\
\hline Estimated Bench Time (hr) & 1.7 & 1.9 \\
\hline Cost (RM) & 990.00 & 1515.00 \\
\hline
\end{tabular}

\subsection{RNA Quality}

The issues of RNA quality was assessed by calculating the $A_{260 / 280}$ ratio to rule out possible DNA and protein contamination. The total RNA was first extracted using RNeasy kit with and without DNase treatment. The results show that the RNA yield were 0.062 for sample with and $0.080 \mu \mathrm{g} / \mu \mathrm{l}$ without DNase treatment with RNA purity of 1.84 and 1.96 respectively. Since the RNA yield and purity results for with and without DNase treatments were very similar, therefore the RNeasy kit with DNase treatment was decided to be further used for this study to serve as control. The Total RNA purification without 
DNase treatment and RNeasy with DNase treatment were then used to extract total RNA and the range of ratios for all types of samples examined was from 1.976 to 2.086 with mean for both methods were close to 2 , which is indicative of pure RNA (Table 3 ).

The quality of RNA was inspected by agarose gel electrophoresis to determine the RNA integrity (Fig. 1). All samples showed bands typical of non-degraded RNA with high intensity of $28 \mathrm{~S}$ and $18 \mathrm{~S}$ fragments. In this regard, it is interesting to note that both methods have their own advantages on providing good quality of RNA for further analysis. The yield of isolated RNA using RNeasy was significantly higher than Total RNA Purification method $(\mathrm{p}=0.004)$. However, there is no significant difference between purity of RNA in the methods compared.

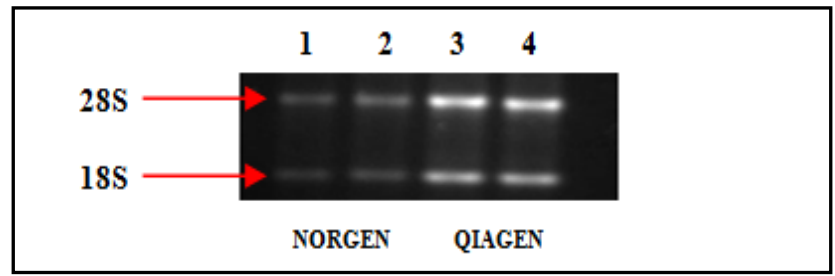

Fig. 1: RNA integrity check for samples extracted from Norgen and Qiagen RNA extraction kit ( $\mathrm{n}=2)$. Lane 1: Sample 1a; (Norgen), 2: Sample 1b ; (Norgen), 3:

Sample 2a; (Qiagen), and 4: Sample 2b ; (Qiagen).

\subsection{Bench Time and Cost}

The extraction time required by both protocol was slightly different. Total RNA Purification method required shorter time due its shorter incubation period in the steps compared to RNeasy method (Table 3). Accurate determination of total RNA concentration is particularly important for absolute quantification of mRNA levels where mRNA copy numbers are best normalized against total RNA and any significant DNA contamination will result in inaccurate quantification [3]. Thus, when time is reduced per sample, it can reduce time for many samples which is good for large number of samples. This would ensure the high quality of samples retained since samples can be processed quickly. In terms of cost, RNeasy kit was more expensive when compared to Total RNA Purification method (Fig. 2).

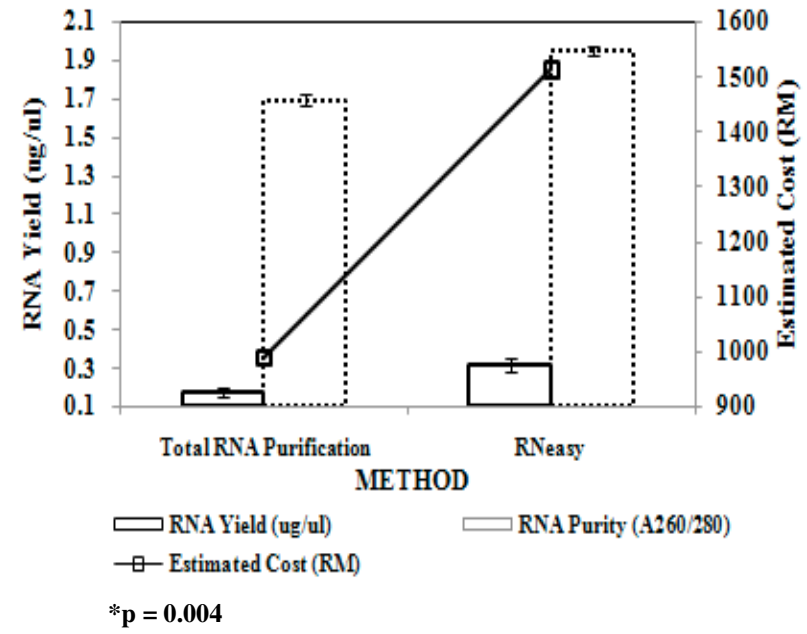

Fig. 2: Comparison of KINA yield, purity and estimated cost (RM) between RNeasy and Total RNA Purification method. 


\subsection{RT-PCR of RNA from CHO-K1 Cells}

For further analysis, the utility of the isolated RNA from CHO-K1 cells was tested by performing reverse-transcriptase PCR (RT-PCR) using Supercript III to build the first strand cDNA. Figure 3 showed the detection of 18 S gene at 219 base pairs. RNA isolated through both methods was suitable for RT-PCR.

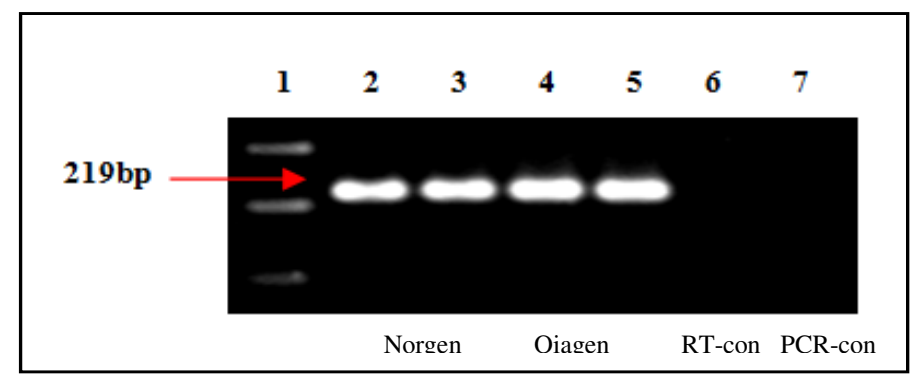

Fig. 3: Amplifiction of 18S cDNA fragments on $2 \%$ agarose gel in 1x TAE buffer.

Lane 1: 100bp DNA ladder, 2: Sample 1a; (Norgen), 3: Sample 1b ; (Norgen), 4: Sample 2a; (Qiagen), 5: Sample 2b ; (Qiagen), 6: RT-con; RT control is without RT enzyme and 7: PCR-con; PCR control is without cDNA template.

\section{CONCLUSION}

In this study, both protocols were found to be suitable for RNA extraction from CHOK1 cell lines. However, Total RNA Purification method is recommended if simplicity, time and cost are a concern while RNeasy method can be used if high yield of RNA is desired. Specifically, since Total RNA Purification method gave comparable result to RNeasy when applied in RT-PCR, use of the former protocol may save overall time and cost as well as maintain the same sample standard through minimizing the cycle time for each sample. This is particularly important when dealing with large number of biological samples.

\section{ACKNOWLEDGEMENTS}

This Project is funded by the Ministry of Education (MOE), Malaysia Grant FRGS 0409110 and supported by Nano Life Quest Sdn. Bhd.

\section{REFERENCES}

[1] Jayapal, K.P., Wlaschin, K.F., Hu, W.S., Yap M.G.S. "Recombinant protein therapeutics from CHO cells - 20 years and counting." Chemical Engineering Progress 103.10 (2007): 40.

[2] Nour, A. M. A., Barbour, E. K., Depint, F. Dooms, M., Niang, K., Dulac, A., Niamba, C. N., Chayaa, G., Pouillart, P. R. "Comparison of five RNA extraction methods from rabbit's blood." Agriculture and Biology Journal of North America, 1.4(2010):448-50.

[3] Bustin, S. A. "Quantification of mRNA using real-time reverse transcription PCR (RTPCR): trends and problems." Journal of Molecular Endocrinology, 29(2002):23-39.

[4] Muyal, J. P., Muyal, V., Kaistha, B. P., Seifart, C., Fehrenbach, H. "Systemic Comparison of RNA Extraction Techniques from Frozen and Fresh Lung Tissues: Checkpoint Towards Gene Expression Studies." Diagnostic Pathology. 4.9(2009):1-8.

[5] Liedtke, W., Battistini, L., Brosnan, C. F. "A Comparison of Methods for RNA Extraction from Lymphocytes for RT-PCR.” Genome Res., 4.(1994):185-87.

[6] NorgenTotal RNA Purification Kit. Thorold: Biotek Corporation.(2010) 
[7] Qiagen. RNeasy® Mini Handbook. USA: Qiagen.(2010)

[8] Wang, X., Seed, B. "A PCR Primer Bank for Quantitative gene Expression Analysis." Nucleic Acids Research, 31.24(2003):154.

[9] Rozen, S., Skaletsky, H.J. "Primer3 on the WWW for the General users and for Biologist Programmers."). Bioinformatics Methods and Protocols: Humana Press, Totowa, NJ., 1999. 365-86. 